Eleonora Kovač Rac

UDC 81`28:811.511.141(497.113)

Filozofski fakultet Univerziteta u Novom Sadu

Originalan naučni rad

kalic@tippnet.rs

\title{
STAVOVI VOJVOĐANSKIH MAĐARA PREMA MAĐARSKIM DIJALEKTIMA $^{1}$
}

Mađarski jezik u Vojvodini je regionalni jezik. Njegova osnova je dijalekat. Ovo se prvenstveno odnosi na govorni varijetet mađarskog jezika. Nastava u školama je ovo sve donedavno zanemarivala. Usvajanje mađarskog standardnog jezika u školi za mađarsku decu predstavlja ozbiljan problem. Nastavni plan predviđa nastavu koja se temelji na standardnom jeziku, i ne uzima u obzir činjenicu da vernakularni maternji jezik većine je dijalekat. Nastava mađarskog jezika - poput švajcarskog i švedskog primera i nastavnih planova maternjeg jezika u Bavarskoj - u budućnosti treba da se temelji na živom govornom jeziku.

Sproveli smo istraživanje stava prema dijalektima mađarskog jezika u Vojvodini i među učenicima i među odraslima. U ovom radu prikazujemo predistoriju istraživanja, dobijene rezultate i mogućnosti daljeg rada.

Ključne reči: jezički stav, stav prema dijalektima mađarskog jezika, govorni mađarski jezik, standardni mađarski jezik, regionalni mađarski jezik, vernakularni maternji jezik, promena jezičkog koda.

\section{UVOD}

Savet Evrope 2001. godine je odredio osam ključnih kompetencija u nastavi. Među njima su komunikacija na maternjem i na stranim jezicima. Tokom komunikacije na maternjem jeziku izražavamo misli, osećanja i stavove u pismu i govoru. Komunikacija na maternjem jeziku predstavlja upotrebu jezika u porodici, prilikom aktivnosti u slobodnom vremenu, u javnoj upotrebi kao što su kulturna dešavanja, javni servisi, nastava i verski obredi. „Ovo znanje obuhvata poznavanje glavnih tipova govorne komunikacije, književnih i neknjiževnih tekstova, glavnih

1 Ovaj rad je urađen u okviru projekta broj 17817 koji finansira Ministarstvo prosvete i nauke Republike Srbije 
crta raznih jezičkih stilova i promena komunikacije u raznim situacijama." (Vass 2008: 14)

U Evropi su regionalni jezici i regionalni govorni jezici sredstvo žive verbalne komunikacije. Regionalni jezici podjednako izražavaju regionalni (u našem slučaju vojvođanski) i lokalni identitet (identitet naselja). Dijalekat je važan element regionalnog jezika. Dijalekte koristimo u različitim komunikacijama. Dijalekti čine govorne jezike bogatijim i širim, beletristici služe kao stilistički izvor, u više evropskih zemalja pomažu u nastavi govornog odnosno maternjeg jezika, a koriste ih i masmediji i industrija zabave.

Dijalekti su često vernakularni maternji jezici članova govorne zajednice. Oni su moguća sredstva izražavanja privrženosti precima i korenima, kao i sredstvo očuvanja identiteta. Komunikacija na maternjem jeziku nam je uspešna ako dobro upoznamo varijetete maternjeg jezika i upotrebljavamo ih u odgovarajućim situacijama. To je preduslov uspešne komunikacije. Ištvan Lanšćak (Lanstyák 2002) i mnogi drugi spominju da i među odraslima i među decom dolazi do nesporazuma tokom komunikacije kada govornici raspolažu ograničenim govornim kodom, tj. ne poznaju razne varijetete jezika. Kada nastavnik dijalekat smatra nekulturnim, neprikladnim i manje vrednim, on kvalifikuje govornu zajednicu u kojoj dete živi. Kada dete smatra dijalekat neprikladnim, kod njega se javlja osećaj stida. Prema Ištvanu Lanšćaku u školstvu treba da se stavlja podjednaki akcenat i na standardni mađarski jezik i na dijalekat koji se govori u određenoj zajednici. (Lanstyák 2002) Zbog ovih razloga je bilo važno izvršiti ispitivanje stava prema mađarskim dijalektima u 5. i 8. razredu u Staroj Moravici, Martonošu, Kupusini, Novom Kneževcu, Skorenovcu, Senti, Novom Bečeju i Tordi.

\section{DIJALEKAT I JEZIČKI STAV}

\subsection{Dijalekti}

U mađarskom jeziku po slojevitosti možemo utvrditi 3 tipa jezičkih varijeteta (vidi A. Jászó 2004):

a) teritorijalne jezičke varijetete, gde spadaju dijalekti i regionalni govorni jezici;

b) društvene jezičke varijetete sa jezicima društvenih grupa i stručnim 
jezicima;

c) standardne i govorne jezičke varijetete koji sadrže i pisanu i usmenu upotrebu jezika.

Opšte uzevši, dijalekat je uglavnom govorni varijetet jednog jezika koji se može vezati uz određenu govornu zonu.

Dijalekte možemo između ostalog ispitivati i po lingvističkom statusu, lingvističkoj sistematizaciji, oblasti primene, krugu korisnika, hronološkom redosledu, teritorijalnoj rasprostranjenosti i komunikacijskom delokrugu.

$\mathrm{O}$ vojvođanskim mađarskim dijalektima objavljene su stručne publikacije u zbirkama tekstova kao što su npr. Hajdu-Kazmer (Hajdú-Kázmér 1974): Nyelvjárási olvasókönyv (Čitanka iz dijalektologije), Ištvan Siling (Silling 2010): Vajdasági magyar nyelvjárási olvasókönyv (Čitanka vojvođanskih dijalekata Mađara), a u Mađarskom dijalekatskom atlasu (Bárczi 1968-1978) se takođe mogu pronaći i podaci koji se odnose na Vojvodinu. Pored njih izdati su i samostalni rečnici, dijalektološki udžbenici, monografije - npr. radovi Jenea Kiša (Kiss 2001) i Geze Sabo (Szabó 1990) -, zatim rad Értekezések, monográfiák 1. (Studije 1.) pod nazivom Jugoszláviai magyar nyelvjárások (Mađarski dijalekti u Jugoslaviji; Szeli 1982) koji je nastao kao rezultat istraživanja dijalekata pod rukovodstvom Olge Penavin, dijalekatski atlasi Bačke (Penavin 1988), Banata (Penavin 1995), Srema (Penavin 1972) i Baranje (Penavin 1969). Možemo da spomenemo i zapise narodnih pesama i narodnih balada Anike Bodor (Bodor 1984) i Ernea Kiralja (Király 1999), zbirke basni i narodnih naziva biljaka (Penavin 2002), ali i radove o narodnim tradicijama i običajima kao što su zbirke arhaičnih molitvi Ištvana Šilinga (Silling 2003), etnografska dela Bele Buranj (Burány 1964) i Rože Boruš (Borús 1981). Serija zbirki banatskih toponima Hungarološkog instituta i Odseka za hungarologiju u Novom Sadu (Penavin 19751988) je takođe zanimljiv za one koji su zainteresovani za dijalekte. Serija pod nazivom A jugoszláviai magyar nyelv rétegei (Slojevi mađarskog jezika u Jugoslaviji; Pénovátz 1975; Marković 1991; Turi 1991) predstavlja obimnu građu o dijalektima mađarskog jezika u Vojvodini prikazivanjem stručnog vokabulara zemljoradnje i uzgoja životinja vojvođanskih mađarskih salaša. Pored ovoga i monografije lokalne istorije pružaju bogat materijal o mađarskim dijalektima u Vojvodini. I naši pisci književnih dela često koriste dijalekatski materijal u svojim delima. Pored ovih, direktnim prethodnikom ovog rada možemo smatrati radove Ilone Rajšli o gubljenju 
dijalekata i promeni stavove među mladim vojvođanskim Mađarima (Rajsli 2004), ali smatramo važnim da napomenemo i istraživanja lingvističkog stava Lajoša Genca (Göncz 1999).

$\mathrm{Na}$ osnovu građe o mađarskoj dijalektologiji i dosada sakupljenih podataka naš cilj je da istražimo jezički odnos prema mađarskim dijalektima u Vojvodini, kao i da - oslanjajući se na mišljenja ispitanika - izradimo udžbenik sa nizom sociolingvističkih zadataka za nastavu dijalekata.

\subsection{Jezički stav}

Jezički stav je stav o jeziku ili jezičkom varijetetu koji pozitivno ili negativno ocenjuje jezik ili jezički varijetet. Jezički stav javlja se u dva aspekta u literaturi.

"Jezički stav manjinskih grupa mogu biti vezane za svoj jezik, jezik većine, dvojezičnost i za jezički purizam.” (Borbély 2001: 30) Nabrajanje se može dopuniti, jer unutar maternjeg jezika postoje različiti jezički slojevi kao što su dijalekat, šatrovački govor, ali ima i puno raznih jezičkih varijeteta. Možemo da govorimo o regionalnim jezicima, kontaktnim i govornim varijetetima.

U novije vreme istraživači prilaze analizama jezičkog stava iz ugla njene funkcije upravljanja ponašanjem: izučavaju kako ona utiče npr. na promenu jezika, na zadržavanje jezika, na opstanak jezika manjinske zajednice, odnosno kako jezički stav manjinske zajednice prema jeziku većine utiče na promenu koda i na promenu jezika. Tako se mogu uočiti kauzalni odnosi između jezičkih pojava.

\section{UKRATKO O ISTRAŽIVANJIMA DIJALEKATSKOG STAVA MAĐARSKOG JEZIKA U VOJVODINI}

Prethodnicima se mogu smatrati autori i radovi koje smo gore naveli, kao i jezik svih mađarskih zajednica izvan granica Mađarske (u Slovačkoj, Transilvaniji, Ukrajini, Slavoniji i Lendavi). Govorni jezik vojvođanskih Mađara nije samo regionalni jezik, nego je i kontaktni varijetet. Regionalni jezik vojvođanskih Mađara u većini sadrži elemente standardnog jezika i dijalekata, dok kontaktni elementi potiču iz većinske govorne zajednice. Ti elementi se najčešće javljaju na nivou leksike, ali se javlja i uticaj na izgovor glasova, kao i na promenu reda reči.

Tokom istraživanja jezičkog stava koje smo sproveli u 16 naselja u Bačkoj i Banatu među odraslim ispitanicima smo primetili da izvorni govornici mađarskog 
jezika u Vojvodini daju prednost upotrebi jezika, odnosno jezičkog varijeteta koji obezbeđuje nesmetano i efikasno obavljanje razgovora. Utvrdili smo da izbor jezika ili jezičkog varijeteta određuje jezička kompetencija, odnosno poznavanje jezika i jezičkih varijeteta komunikacijskih partnera. Pored ovoga na izbor jezika utiču i lokacija situacije, školska sprema govornika i njihova starosna dob. Tokom istraživanja jezičkog stava među odraslima utvrdili smo da govorni jezik svoga naselja ispitanici smatraju manje lepšim i korisnim nego standardni mađarski jezik (vidi Kovač Rac 2011). Međutim, po sopstvenoj proceni ipak često koriste govorni jezik naselja u svojim razgovorima. Korisnost govornog mađarskog jezika (u 60,79\%) obrazlažu time da im zadovoljava mesne komunikacijske potrebe, govorna zajednica ga poznaje i očekuje ovaj jezički varijetet tokom komunikacije. Govorni jezik svog naselja ispitanici smatraju jezičkim bogatstvom, i ovaj jezički varijetet im znači identitet, pripadanje zajednici.

Želeli bismo da istražimo da li se javljaju gore navedeni argumenti kod učenika viših razreda osnovnih škola. Rezultat istraživanja može da pruži važne podatke za nastavne planove iz mađarskog maternjeg jezika.

Tokom istraživanja jezičkog stava koju smo sproveli među odraslima ispitivali smo i stavove prema dijalektima. $85,83 \%$ ispitanika procenjuje da govori mađarski dijalekat svoga naselja. Zanimljivo je da smo po tom pitanju najveće razlike uočili kada smo posmatrali starosnu dob ispitanika. Najviše njih je procenilo da govori dijalekat svog naselja u Banatu, i to žene i muškarci od 31. do 50. godina.

Još jedna anketa je sprovedena u Banatu (Kovács Rácz 2012). Utvrđeno je da ispitanici gaje pozitivne stavove prema sopstvenom dijalektu. Vole mađarski dijalekat svog naselja, ne stide ga se i često ga koriste u govornom jeziku. Došli smo do zaključka da prema dijalektu postoji pretežno pozitivni stav u naseljima gde se podjednako može koristiti i u intimnim razgovorima kao i u javnim komunikacijskim situacijama npr. u prodavnici, domovima zdravlja, javnim institucijama. Primetili smo da u gradovima (npr. u Zrenjaninu) pozitivni stav prema dijalektu gaje pre svega doseljenici sa sela. Dijalekat upotrebljen u detinjstvu i pozitivni stav su srazmerni. Na osnovu dobijenih odgovora upotreba dijalekta se može dovoditi pre svega u vezu sa poslom i vrstom delatnosti a ne sa školskom spremom, kako smo očekivali. Oni inženjeri, frizeri, sekretari, učitelji i nastavnici koji su zbog prirode posla u dodiru sa standardnim jezikom, situativno menjaju kod, i u zavisnosti od govorne situacije 
mogu koristiti i dijalekat. Posao, vrsta delatnosti i poznavanje određenih jezičkih varijeteta su u tesnoj vezi. Ova konstatacija je važna, jer u sociolingvistici je sporno pitanje u kolikoj meri utiču okolnosti na stav prema dijaleku.

Ohrabreni delimično pozitivnim stranim primerima, a i zbog ličnog interesovanja, nastavili smo ispitivanje jezičkih stavova prema dijalektima u 5 . i 8. razredima vojvođanskih osnovnih škola sa mađarskim nastavnim jezikom. Naš cilj je da se obrati pažnja na stavove učenika prema sopstvenim dijalektima. Nastavni planovi na žalost uglavnom ignorišu postojanje vernakularnog maternjeg jezika. Učiteljski fakultet na mađarskom nastavnom jeziku u Subotici i Odsek za hungarologiju u Novom Sadu su uočili problem, i na časovima obraćaju studentima pažnju na uvođenje dijalekata u nastavu, kao i na njegovu povezanost sa situacijom. $\mathrm{Na}$ Odseku za hungarologiju u Novom Sadu u sklopu predmeta "Sociolingvistika", "Dijalektološki tekstovi" i "Dijalektologija" očekujemo od studenata izradu niza zadataka. Primere smo predstavili i profesorima koji pohađaju seminare Odseka za hungarologiju. Nadamo se da će zbog preduzetih koraka uskoro krenuti nastava pozitivnog odnosa prema dijalektima u nižim i višim razredima osnovnih škola.

\section{ODREĐIVANJE I DEFINISANJE DIJALEKTA KOD UČENIKA}

\subsection{Funkcionalni pristup}

Prilikom našeg istraživanja jezičkih stavova pošli smo od definicije maternjeg jezika koji su dali Skutnab i Kangas. Zatim smo obradili funkcije dijalekata, i na kraju smo želeli da ocenimo u kojoj meri su svesni đaci 5. i 8. razreda stigmatizacije dijalekata.

Funkcije dijalekata su one uloge koje dijalekat može imati u životu jedne zajednice. Njih možemo sažeti na sledeći način:

a) Njihove komunikativne i kognitivne funkcije obezbeđuju jezičku komunikaciju među članovima zajednice.

b) Funkcija dijalekata je i da simbolišu identitet i koheziju društva, tj. označavaju društvenu pripadnost govornika.

c) Dijalekti su nosioci i (delom) stvaraoci mesne kulture (Kiss 2001: 47-56)

Ove funkcije su čvrsto povezane sa negativnom ocenom dijalekata, odnosno sa stigmatizacijom. Ukoliko su navedene funkcije široko rasprostranjene među 
članovima jedne zajednice, negativni društveni stav, tj. stigmatizacija u manjoj meri utiče na upotrebu dijalekta. Zato smatramo da je u našem istraživanju bitno baviti se sa oba ova stava (odnosom prema dijalektu i stigmatizacijom). Želimo da ocenimo u kojoj meri su svesni ovih činjenica učenici 5. i 8. razreda.

Definiciju maternjeg jezika smo povezali sa dijalektom u našoj anketi na sledeći način: pošto je kod velike većine vojvođanskih Mađara (i učenika i odraslih) dijalekat primarni jezički varijetet, ovo je

a) u detinjstvu prvo usvojeni jezik;

b) govornici se njime poistovećuju;

c) drugi ih njime poistovećuju;

d) oni koji su usvojili ovaj jezički varijetet njega i poznaju najbolje;

e) kao deo regionalnog govora, u skladu sa očekivanjima sredine i govornom praksom, govornici sa sela (i delom iz gradova) najčešće ovaj jezički varijetet koriste.

Definicija maternjeg jezika Skutnab-Kangasa je tesno povezan sa definicijom funkcija dijalekata što se vidi iz sledećeg:

a) Dijalekti obezbeđuju jezičku komunikaciju među članovima zajednice. Više ispitanika 5. i 8. razreda osnovnih škola su aludirali na ovo kad su izjavili da u naselju skoro svi govore dijalekat jer su to naučili od roditelja i predaka. Ova definicija je istovetna sa Skutnab-Kangasovom kategorijom prvog naučenog jezika.

b) Dijalekti su po funkcionalnom pristupu simboli sloge i zajedništva zajednica. U odgovorima ispitanika srećemo i definicije koje upotrebu dijalekta objašnjavaju navikom, čestom upotrebom i ljubavlju. Zapravo se korisnici dijalekta na taj način poistovećuju sa dijalektom.

c) Funkcionalni pristup dijalektima u trećoj tačci ističe značaj veze lokalne kulture i dijalekta. Prema ovoj definiciji dijalekti su nosioci i čuvari kulture naselja. Prema našem mišljenju ovaj argument je zanemaren u nastavi maternjeg jezika. Nastava narodne muzike i kulture bi mogla da bude značajan deo nastave jezika. Ovaj nedostatak delimično nadoknađuju kulturna udruženja, međutim ne treba zaboraviti da samo zanemarljivi deo učenika učestvuje u njihovom radu. Kultura bi trebalo da nađe svoje mesto u redovnoj školskoj nastavi. Gore navedeni podaci se javljaju u anketama u sklopu pitanja vezanih za stav. 
Pored gore navedenih, $\mathrm{u}$ anketama smo dijalekte ispitivali $\mathrm{i}$ po stigmatiziranosti, upotrebi jezika i vezanosti za naselje. Stigmatizacija je devalvacija značaja, i ona nastaje na osnovu onih karakteristika koje se smatraju negativnim. Jezička stigmatizacija znači negativno ocenjivanje nestandardnih jezičkih elemenata u poređenju sa elementima standardnog jezika, tj. jezika otvorenog prestiža - ovi potonji se smatraju ispravnim, prihvaćenim, i one su preporučene forme jezičke upotrebe koje treba slediti (Kiss 1995).

Stigmatizacija dijalekata znači da su te jezičke forme u društvu negativno ocenjeni. Međutim, to ne znači da i govornici dijalekata negativno ocenjuju svoj jezički varijetet, i da ga ne koriste u prisustvu stranaca.

Istraživanje stava prema dijalektima sadrži i pitanja vezano za stav koji su tesno povezani sa osećajem vezanosti za naselje i za budućnost dijalekata. U vezi budućnosti ovih jezičkih varijeteta postavili smo pitanje da li je važan opstanak dijalekta.

Što se tiče naselja i njegovih jezičkih formi postavili smo sledeća pitanja: Kakvim smatrate dijalekat svoga naselja? Šta izražavaju učenici upotrebom svog dijalekta?

Ispitivanje jezičkog stava se odnosi na upotrebu jezika i na usmenu upotrebu dijalekata. Želeli bismo pogledati koliko je svesna upotreba dijalekatskog leksikona u jezičkoj upotrebi mladih, odnosno uopšte stanovnika naselja.

U istraživanju ispitaćemo mogućnost doživljavanja dijalekta kao jezičke mane iz tri aspekta:

a) da li učenici koji govore dijalekat doživljavaju diskriminaciju prilikom njegovog korišćenja;

b) da li su se susreli sa negativnim društvenim stavom prema dijalektima;

c) da li se vrednosni stavovi prema dijalektima menjaju teritorijalno (po naseljima).

\section{IZVORI I LITERATURA}

Bárczi, Géza-Deme, László-Imre, Samu (1968-1978). A magyar nyelvjárások atlasza I-VI. Budapest: Akadémiai Kiadó.

Bodor, Anikó (1984). Az al-dunai székelyek népdalai (Narodne pesme 
Mađara s donjeg toka Dunava). Újvidék: A Magyar Nyelv, Irodalom és Hungarológiai Kutatások Intézete.

Borbély, Anna (2001). Nyelvcsere. Szociolingvisztikai kutatások a magyarországirománok közösségében (Promenajezika. Sociolingvistička istraživanja u zajednici Rumuna u Mađarskoj). Budapest: Készült az MTA Nyelvtudományi Intézetének Élőnyelvi Osztályán.

Borús, Rózsa (1981). Topolya népszokásai (Narodni običaji u Bačkoj Topoli). Újvidék: A Magyar Nyelv, Irodalom és Hungarológiai Kutatások Intézete.

Burány, Béla (1964). Zentavidéki népballadák (Balade iz okoline Sente). Zenta: Művelödési Központ.

Göncz, Lajos (1999). A magyar nyelv Jugoszláviában (Vajdaságban) (Mađarski jezik u Jugoslaviji (u Vojvodini). Budapest-Újvidék: Osiris-Forum-MTA Kisebbségkutató Mühely.

Hajdú, Mihály-Kázmér, Miklós (1974). Magyar nyelvjárási olvasókönyv. (Čitanka mađarskih dijalekata) Budapest: Tankönyvkiadó.

Király, Ernő 1999. Gyöngykaláris. Jugoszláviai magyar népénekek (Đenđkalariš. Jugoslovenske mađarske narodne pesme). Forum, Újvidék.

Kiss, Jenő (1995). Társadalom és nyelvhasználat (Društvo $i$ upotreba jezika). Budapest: Nemzeti Tankönyvkiadó.

Kiss, Jenő (szerk. 2001). Dialektológia (Dijalektologija). Budapest: Osiris Kiadó.

Kovács Rácz, Eleonóra (2011). Nyelvi attitüdök a vajdasági magyarság körében (Jezički stavovi kod vojvođanskih Mađara). Újvidék: Sajnos.

Kovács Rácz, Eleonóra (2012). A bánáti adatközlők véleménye a nyelvjárásról (Stav banaćanskih ispitnika prema dijalektu) Hungarológiai Közlemények (Hungarološka Saopštenja) XLII/3. 93-107.

Lanstyák, István (2002). Magyar nyelvtervezés a Kárpát-medencében a 21. században (Planiranje mađarskog jezika u 21. veku u Karpatskom basenu). = Lanstyák István-Szabómihály Gizella (szerk.): Magyar nyelvtervezés Szlovákiában (Planiranje mađarskog jezika u Slovačkoj). Pozsony: Kalligram Kiadó, 127-141.

Marković, Radmila (1991). A kishegyesi földmüvelés és állattartás szókincse (Leksika poljoprivrede i stočarstva u Malom Iđošu). Újvidék: A Magyar Nyelv, Irodalom és Hungarológiai Kutatások Intézete. 
Penavin, Olga (1969). A jugoszláviai Baranya Magyar tájnyelvi atlasza (Dijalekatski atlas Mađara u Baranji). Újvidék: Forum.

Penavin, Olga (1972). A szerémségi magyar szigetek nyelve (Dijalekatski atlas Mađara $u$ Sremu). Újvidék: Forum.

Penavin, Olga (1975-1988). Vajdaság helységeinek földrajzi nevei 1-14. (Zbirka banatskih toponima). Újvidék: Magyar Nyelv, Irodalom és Hungarológiai Kutatások Intézete.

Penavin, Olga (1988). Bácskai magyar nyelvjárási atlasz (Dijalekatski atlas Mađara u Bačkoj). Újvidék: A Magyar Nyelv, Irodalom és Hungarológiai Kutatások Intézete

Penavin, Olga (1995). A jugoszláviai Bánát magyar nyelvjárási atlasza (Dijalekatski atlas Mađara Banata). Kanizsa: Cnesa.

Penavin, Olga (2002). Bácskai és bánáti (népi) növénynevek (Zbirka narodnih naziva biljaka Banata). Újvidék: Forum.

Pénovátz, Antal (1975). A pacséri földmüvelés és állattartás szótára (Leksika poljoprivrede i stočarstva u Pačiru). Újvidék: Hungarológiai Intézet.

Rajsli, Ilona (2004). Nyelvjárásvesztés és attitűdváltás a vajdasági magyar fiatalok körében (Gubljenje jezika i promena stava među mladim vojvođanskim Mađarima). = P. Lakatos Ilona-T. Károlyi Margit (szerk.). Nyelvvesztés, nyelvjárásvesztés, nyelvcsere. A 13. Élönyelvi Konferencia elöadásai (Gubljenje jezika, gubljenje dijalekta, promena jezika. Predavanja 13. Konferencije govornih jezika). Budapest: Tinta Könyvkiadó, 146-152.

Silling, István (2003). Vajdasági népi imádságok és nyelvezetük (Zbirke arhaičnih molitvi). Újvidék: Forum Könyvkiadó.

Silling, István (2010). Vajdasági magyar nyelvjárási olvasókönyv (Čitanka vojvođanskih mađarskih dijalekata). Egyetemi segédlet. Újvidék-Szabadka: Forum Könyvkiadó, Újvidék és Újvidéki Egyetem, Magyar Tannyelvű Tanítóképző Kar.

Szabó, Géza (1990). A magyar nyelvjárások (Dijalekti mađarskog jezika). Budapest: Tankönyvkiadó.

Szeli, István (1982). Jugoszláviai magyar nyelvjárások (Dijalekti mađarskog jezika u Jugoslaviji). Újvidék: A Magyar Nyelv, Irodalom és Hungarológiai Kutatások Intézete.

Turi, Márta (1991). A Kanizsa környéki tanyavilágföldmüvelésének szókincse 
(Leksika poljoprivrede salaša u okolini Kanjiže). Újvidék: A Magyar Nyelv, Irodalom és Hungarológiai Kutatások Intézete.

Vass, Vilmos (2008). A kulcskompetenciák fejlesztése és értékelése (vitaanyag) (Razvijanje i vrednovanje ključnih kompetencija (građa za diskusiju). = Krémó Anita (szerk.) Oktatás és Képzés 2010. Mühelybeszélgetések 2007 (Obrazovanje i nastava 2010. Razgovori radionice 2007). Budapest: Oktatási és Kulturális Minisztérium 13-18.

Eleonóra Kovács Rácz

OPINIONS ABOUT THE DIALECT OF THE HUNGARIAN SPEAKING INFORMANTS LIVING IN VOJVODINA

\section{Summary}

The study was conducted among the Hungarian speaking adults and school-children. It presents the points of contact of the attitude research and also its connections. Furthermore, it elaborates on clarifying the theoretical concept of the language attitude research, as well as presenting the sociolinguistical approaches which help children define their settlements' dialect and also state their opinions about the dialect's stigma and use.

This study is part of the European dialect research, it can be the continuation of other nations in Vojvodina and their dialect's sociolinguistical assessment, the comparison of the received results.

Key words: language attitude, attitude towards Hungarian dialects, Hungarian spoken language, Hungarian standard language, Hungarian regional language, vernacular mother tongue, code-switching. 